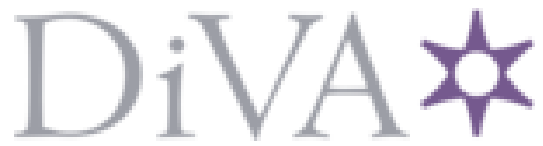

http://www.diva-portal.org

This is the published version of a paper published in Environmental Science and Technology.

Citation for the original published paper (version of record):

Song, Y., Adediran, G A., Jiang, T., Hayama, S., Björn, E. et al. (2020)

Toward an Internally Consistent Model for $\mathrm{Hg}$ (II) Chemical Speciation Calculations in

Bacterium-Natural Organic Matter-Low Molecular Mass Thiol Systems

Environmental Science and Technology, 54(13): 8094-8103

https://doi.org/10.1021/acs.est.oc01751

Access to the published version may require subscription.

N.B. When citing this work, cite the original published paper.

Permanent link to this version:

http://urn.kb.se/resolve?urn=urn:nbn:se:umu:diva-173770 


\section{Toward an Internally Consistent Model for Hg(II) Chemical Speciation Calculations in Bacterium-Natural Organic Matter-Low Molecular Mass Thiol Systems}

Yu Song,* Gbotemi A. Adediran, Tao Jiang, Shusaku Hayama, Erik Björn, and Ulf Skyllberg*

Cite This: Environ. Sci. Technol. 2020, 54, 8094-8103

Read Online

\section{ACCESS |}

Џlll Metrics \& More

回国 Article Recommendations

Supporting Information

ABSTRACT: To advance the scientific understanding of bacteriadriven mercury $(\mathrm{Hg})$ transformation processes in natural environments, thermodynamics and kinetics of divalent mercury $\mathrm{Hg}$ (II) chemical speciation need to be understood. Based on $\mathrm{Hg} \mathrm{L}_{\mathrm{III}}$-edge extended X-ray absorption fine structure (EXAFS) spectroscopic information, combined with competitive ligand exchange (CLE) experiments, we determined $\mathrm{Hg}$ (II) structures and thermodynamic constants for $\mathrm{Hg}$ (II) complexes formed with thiol functional groups in bacterial cell membranes of two extensively studied $\mathrm{Hg}$ (II) methylating bacteria: Geobacter sulfurreducens PCA and Desulfovibrio
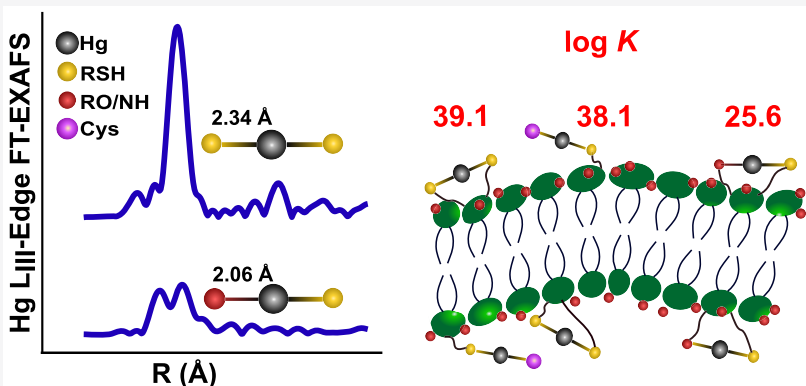
desulfuricans ND132. The Hg EXAFS data suggest that 5\% of the total number of membranethiol functionalities (Mem- $\mathrm{RS}_{\text {tot }}=380 \pm 50 \mu \mathrm{mol} \mathrm{g}{ }^{-1} \mathrm{C}$ ) are situated closely enough to be involved in a 2-coordinated $\mathrm{Hg}(\mathrm{Mem}-\mathrm{RS})_{2}$ structure in Geobacter. The remaining 95\% of Mem-RSH is involved in mixed-ligation $\mathrm{Hg}(\mathrm{II})$ complexes, combining either with low molecular mass (LMM) thiols like Cys, $\mathrm{Hg}(\mathrm{Cys})(\mathrm{Mem}-\mathrm{RS})$, or with neighboring $\mathrm{O} / \mathrm{N}$ membrane functionalities, $\mathrm{Hg}(\mathrm{Mem}-\mathrm{RSRO})$. We report $\log \mathrm{K}$ values for the formation of the structures $\mathrm{Hg}(\mathrm{Mem}-\mathrm{RS})_{2}$, $\mathrm{Hg}$ (Cys)(Mem-RS), and $\mathrm{Hg}(\mathrm{Mem}-\mathrm{RSRO})$ to be $39.1 \pm 0.2,38.1 \pm 0.1$, and $25.6 \pm 0.1$, respectively, for Geobacter and $39.2 \pm 0.2$, $38.2 \pm 0.1$, and $25.7 \pm 0.1$, respectively, for ND132. Combined with results obtained from previous studies using the same methodology to determine chemical speciation of $\mathrm{Hg}$ (II) in the presence of natural organic matter (NOM; Suwannee River DOM) and 15 LMM thiols, an internally consistent thermodynamic data set is created, which we recommend to be used in studies of $\mathrm{Hg}$ transformation processes in bacterium-NOM-LMM thiol systems.

\section{INTRODUCTION}

Methylmercury (MeHg), a highly toxic pollutant that poses a serious risk to humans and ecosystems, is primarily produced by microbial methylation of inorganic divalent mercury, $\mathrm{Hg}(\mathrm{II}) .^{1-3}$ In addition to the activity of the methylating organisms, $\mathrm{MeHg}$ formation is controlled by the bioavailability and biouptake of $\mathrm{Hg}(\mathrm{II})$ species, ${ }^{4}$ where reactions with reduced sulfur (including inorganic sulfide and organic thiol functional groups) are of utmost importance. ${ }^{1,5}$

Thiol groups associated with the outer or inner cell membranes (Mem-RSH) have been proposed to play an important role in the uptake of $\mathrm{Hg}$ (II) by bacteria capable of methylation and reduction. ${ }^{6-9}$ Membrane associated thiols have been suggested as being a part of the critical step for $\mathrm{Hg}$ (II) uptake. $^{10,11}$ In contrast, adsorption of $\mathrm{Hg}(\mathrm{II})$ onto the outer cell membrane has also been proposed to inhibit the uptake by bacteria by lowering the aqueous $\mathrm{Hg}$ (II) concentration, as demonstrated for $\mathrm{Hg}$ (II) methylation 6,7 and reduction. 8 Thiol functional groups of the $\mathrm{Hg}$ (II) transporters MerC and MerT, associated with the inner cell membrane, are known to form well-defined chemical structures with $\mathrm{Hg}(\mathrm{II}) .{ }^{12}$ Current models for microbial uptake of metals, such as the free-ion activity model, biotic ligand model, and surface complexation models ${ }^{13-18}$ build on the assumption that the free $\mathrm{Hg}$ (II) ions or $\mathrm{Hg}$ (II) complexes in solution are in chemical equilibrium with $\mathrm{Hg}$ (II) bonded to the outer cell membrane functional groups.

In spite of the indicated importance of the Mem-RSH functional group and its complexation with $\mathrm{Hg}(\mathrm{II})$, only a few studies have determined chemical structures formed between $\mathrm{Hg}$ (II) and Mem-RSH functional groups in the outer membrane. ${ }^{9,19}$ There is so far no reported data on the thermodynamic stability of these structures, with reports limited to the distribution (partitioning coefficient) of $\mathrm{Hg}$ (II) between the aqueous phase and the cell surface. ${ }^{20-22}$ This lack of information is partly explained by the challenge to quantitate Mem-RSH functionalities. One principal type of

Received: March 20, 2020

Revised: June 1, 2020

Accepted: June 3, 2020

Published: June 3, 2020 
methodology builds on the use of fluorescent probes forming covalent, nonreversible bonds with thiols, followed by either fluorescence spectroscopy ${ }^{23,24}$ or potentiometry ${ }^{25}$ measurements to quantify the thiols. The accuracy of this method is dependent on matrix effects affecting the fluorescence and its quenching. ${ }^{24}$ Another possibility is to use $\mathrm{Hg} \mathrm{L} \mathrm{L}_{\mathrm{III}}$-edge extended X-ray absorption fine structure (EXAFS) spectroscopy, which is element specific and essentially matrix independent. The concentration of thiol groups is determined by a titration method, where the concentration of Mem-RSH can be calculated from the coordination number and bondlengths of $\mathrm{Hg}-\mathrm{O} / \mathrm{NR}$ and $\mathrm{Hg}-\mathrm{SR}$ structures formed at stepwise additions of $\mathrm{Hg}(\mathrm{II}) .{ }^{19}$ The method has been previously used to determine the concentration of RSH groups associated with natural organic matter (NOM) functional groups, using either $\mathrm{MeHg}$ or $\mathrm{Hg}$ as the probe. ${ }^{26-28}$

Here, we use a competitive ligand exchange (CLE) method where cysteine (Cys) is added as a competitor with Mem-RSH for $\mathrm{Hg}(\mathrm{II})$, to establish thermodynamic constants for complexes formed between $\mathrm{Hg}$ (II) and Mem-RSH functional groups of Geobacter sulfurreducens PCA and Desulfovibrio desulfuricans ND132, two Gram-negative bacteria frequently used in assay studies of $\mathrm{Hg}$ (II) transformation reactions. The concentration of the $\mathrm{Hg}(\mathrm{Cys})_{2}$ complex in equilibrium with $\mathrm{Hg}$ (II) complexes formed with Mem-RSH is determined by liquid chromatography inductively coupled plasma mass spectrometry (LC-ICPMS). The method has previously been used to determine stability constants $(\log K)$ for the bonding of $\mathrm{Hg}(\mathrm{II})$ to 15 different LMM-RSH, as well as with NOM associated thiols (NOM-RSH). ${ }^{28,29}$ Mercury $\mathrm{L}_{\mathrm{III}}$-edge EXAFS data, complemented with sulfur K-edge X-ray absorption nearedge structure (XANES) data, were used to characterize the cell membrane sulfur groups to determine the concentration of Mem-RSH groups, and to provide direct spectroscopic evidence for structures of $\mathrm{Hg}$ (II) complexes formed with Mem-RSH functionalities. Combined with data from previous studies, ${ }^{28,29}$ the overarching goal is to provide an internally consistent set of $\log K$ values for well-defined $\mathrm{Hg}$ (II) complexes and structures formed with LMM-RSH, NOM$\mathrm{RSH}$, and bacterial Mem-RSH functionalities. We recommend applying this thermodynamically consistent data set to studies of microbial driven $\mathrm{Hg}(\mathrm{II})$ transformation processes in the presence of LMM thiols and NOM to improve the molecular scale understanding of the processes of $\mathrm{Hg}$ (II) bacterial uptake, reduction/oxidation, and methylation in a relatively complex environment.

\section{MATERIALS AND METHODS}

Bacterial Cultures and Membrane Isolation. Geobacter sulfurreducens $\mathrm{PCA}^{30}$ and Desulfovibrio desulfuricans ND132 were harvested at late exponential phase $\left(\mathrm{OD}_{660} \sim 0.5\right)$ as described in previous studies. ${ }^{31,32}$ The membrane isolation procedure was modified from standard protocols ${ }^{33}$ to expose all accessible thiol groups on both inner and outer membranes. ${ }^{33,34}$ Extracellular metabolites were separated from the membranes in the assay buffer solutions by filtration using $0.2 \mu \mathrm{m}$ filters. ${ }^{35}$

Details about bacterial cultures, membranes, and extracellular metabolite isolation are given in the Supporting Information.

Membrane and Cell Sample Preparation and Characterization. The total organic carbon (TOC) content of the whole cells and isolated membranes were determined by an elemental analyzer-isotope ratio mass spectrometer (Flash 2000, Thermo Fisher Scientific). The sulfide concentration in the assay media for both Geobacter and ND132 was determined by the methylene blue method (LOD $=0.3$ $\mu \mathrm{M}) .^{36}$ Sulfur K-edge XANES data were collected on freezedried samples of whole cells, membranes, and extracellular metabolites. Mercury $\mathrm{L}_{\mathrm{III}}$-edge EXAFS analysis was conducted on freeze-dried and frozen membrane samples.

In a first set of samples, aliquots of $\mathrm{Hg}\left(\mathrm{NO}_{3}\right)_{2}$ stock solutions were added to the membranes of Geobacter and ND132 to get a final $\mathrm{Hg}$ (II) concentration of 32 and 610$1220 \mu \mathrm{mol} \mathrm{g}^{-1} \mathrm{C}$, respectively. After $2 \mathrm{~h}$ of reaction, the membrane suspensions were frozen at $-80{ }^{\circ} \mathrm{C}$, freeze-dried, and pressed into $5 \mathrm{~mm}$ diameter pellets for later use. In a second set of samples, isolated Geobacter membranes were added an $\mathrm{Hg}$ (II) content of $8-834 \mu \mathrm{mol} \mathrm{g}^{-1} \mathrm{C}$. After $2 \mathrm{~h}$ of reaction, the samples were ultracentrifuged (at $160000 \mathrm{~g}$ ) and the pellets were rinsed with deoxygenated Milli-Q water three times before being frozen at $-80^{\circ} \mathrm{C}$ in $5 \mathrm{~mm}$ diameter Teflon holders. Both sets of samples were stored at $-80^{\circ} \mathrm{C}$ until X-ray absorption spectroscopy analyses.

Competitive Ligand Exchange Experiments. The isolated membranes were suspended in deoxygenated $\mathrm{NaClO}_{4}(10 \mathrm{mM})$ solutions in $15 \mathrm{~mL}$ polypropylene tubes (Sarstedt) to make a final membrane concentration of 1-19 $\mathrm{mg} \mathrm{C} \mathrm{L} \mathrm{L}^{-1}$ for Geobacter and 1-27 $\mathrm{mg} \mathrm{C} \mathrm{L}^{-1}$ for ND132. Aliquots of $\mathrm{Hg}\left(\mathrm{NO}_{3}\right)_{2}$ stock solution were added to yield a final concentration of $0.5 \mu \mathrm{M}$ allowed to react for $24 \mathrm{~h}$ with the cell membrane sample. Although the reaction of $\mathrm{Hg}$ (II) with Mem-RSH is expected to be kinetically controlled, 24 h should with marginal be sufficient to allow equilibrium to be reached according to previous studies of $\mathrm{Hg}$ (II) with thiols of NOM, cells and membranes. ${ }^{19,21,28,37}$ Finally, aliquots of Cys stock solution were added to obtain a final concentration of $2.0 \mu \mathrm{M}$. This solution was then sampled for total $\mathrm{Hg}(\mathrm{II})\left(\mathrm{Hg}_{\text {tot }}\right)$ and $\mathrm{Hg}(\text { Cys })_{2}$ analysis at the time of 1, 24, 48 and $72 \mathrm{~h}$. Parallel experiments with $0.5 \mu \mathrm{M} \mathrm{Hg}$ (II) and $2.0 \mu \mathrm{M}$ Cys prepared in deoxygenated Milli-Q water in the absence of membrane were used as controls. All experiments were duplicated. The reaction vessels were protected from light by aluminum foil and maintained at $25 \pm 1{ }^{\circ} \mathrm{C}$ with a thermostat in the $\mathrm{N}_{2}$ filled glovebox. To avoid introducing potential interference, no $\mathrm{pH}$ buffer was added and $\mathrm{pH}$ was maintained at $\sim 4.0$.

Total $\mathrm{Hg}$ and $\mathrm{Hg}(\mathrm{Cys})_{2}$ Analyses. The $\mathrm{Hg}_{\text {tot }}$ concentration was determined by combustion atomic absorption spectrometry (CAAS) using a direct mercury analyzer (DMA80 , Milestone, $\mathrm{RSD}=6 \%)$. The concentration of $\mathrm{Hg}(\mathrm{Cys})_{2}$ was determined by LC-ICPMS $(\mathrm{RSD}=10 \%){ }^{29}$

X-ray Absorption Spectroscopy Analyses. We applied sulfur K-edge XANES and $\mathrm{Hg} \mathrm{L}_{\mathrm{III}}$-edge EXAFS to characterize the sulfur chemistry at the bacterial cells and membranes as well as to quantify the membrane-associated thiol groups. Details about these two methods are given in the Supporting Information.

Thermodynamic Calculations. Thermodynamic calculations were conducted in the software $\mathrm{R}^{38}$ using the PHREEQC package $e^{39,40}$ and following the protocol used in a previous study of the complexation $\mathrm{Hg}$ (II) with NOM-RSH functional groups. ${ }^{28}$ In Table S1, reactions and constants expected to dominate the $\mathrm{Hg}$ (II) chemical speciation in bacterium-NOM-LMM thiol systems are listed. Experimental uncertainties in the reported $\log K$ values were propagated 
Table 1. First Coordination Shell Model Fits to $\mathrm{Hg} \mathrm{L} \mathrm{L}_{\mathrm{III}}$-Edge EXAFS R-Space Data for the Isolated Membranes of Geobacter and ND132 with Different Concentrations of $\mathrm{Hg}(\mathrm{II})^{a}$

\begin{tabular}{|c|c|c|c|c|c|c|c|c|c|c|}
\hline & \multirow[b]{2}{*}{$\mathrm{Hg}_{\text {added }}$} & \multirow[b]{2}{*}{$\mathrm{Hg}_{\text {tot }}$} & \multicolumn{3}{|c|}{ first $S$ shell } & \multicolumn{3}{|c|}{ first O shell } & \multirow[b]{2}{*}{$\Delta E_{0}(\mathrm{eV})$} & \multirow[b]{2}{*}{$k$-range $\left(\AA^{-1}\right)$} \\
\hline & & & $\mathrm{CN}$ & $R(\AA)$ & $\sigma^{2}\left(\AA^{2}\right)$ & $\mathrm{CN}$ & $R(\AA)$ & $\sigma^{2}\left(\AA^{2}\right)$ & & \\
\hline \multirow[t]{5}{*}{ Geobacter } & $8^{b}$ & 4 & 2.00 & 2.34 & 0.003 & & & & 7.4 & $2.7-13.5^{d}$ \\
\hline & $32^{c}$ & 28 & 1.43 & 2.37 & 0.003 & 0.48 & 2.08 & 0.003 & 10.1 & $2.7-9.8^{d}$ \\
\hline & $83^{b}$ & 55 & 1.13 & 2.36 & 0.003 & 0.87 & 2.08 & 0.003 & 9.7 & $2.7-13.5^{d}$ \\
\hline & $324^{c}$ & 215 & 0.73 & 2.39 & 0.003 & 0.64 & 2.04 & 0.003 & 7.3 & $2.7-12.0^{e}$ \\
\hline & $834^{b}$ & 406 & 0.61 & 2.39 & 0.003 & 0.70 & 2.03 & 0.003 & 8.9 & $2.7-12.1^{d}$ \\
\hline \multirow[t]{2}{*}{ ND132 } & $610^{c}$ & 397 & 0.59 & 2.40 & 0.006 & 0.78 & 2.06 & 0.003 & 9.8 & $2.7-13.1^{e}$ \\
\hline & $1220^{c}$ & 436 & 0.58 & 2.39 & 0.004 & 0.83 & 2.05 & 0.003 & 8.6 & $2.7-12.6^{e}$ \\
\hline
\end{tabular}

${ }^{a} \mathrm{Hg}_{\text {added }}$ denotes the theoretical added $\mathrm{Hg}$ concentration and $\mathrm{Hg}_{\text {tot }}$ denotes the final determined total $\mathrm{Hg}$ concentration (unit, $\mu$ mol $\mathrm{g}^{-1} \mathrm{C}$ ) in samples subjected to EXAFS measurements. CN denotes coordination number, $R$ denotes bond distance, $\Delta E_{0}$ denotes edge energy shift, and $\sigma^{2}$ denotes the Debye-Waller factor which is constrained to $0.003-0.01 \AA^{2}$; the amplitude reduction factor, $S_{0}{ }^{2}$, is fixed to 0.9 for all samples. ${ }^{b}$ Frozen samples. ${ }^{c}$ Freeze-dried samples. ${ }^{d}$ Seven knots used in spline fit of $k^{3}$ weighted data. ${ }^{e}$ Eight knots used in spline fit of $k^{3}$ weighted data.

using the first-order Taylor series method calculated by the $\mathrm{R}$ package errors. $^{41}$

\section{RESULTS AND DISCUSSION}

Sulfur Speciation of Bacteria Characterized by Sulfur K-Edge XANES. Total organic carbon (TOC) content accounted for 51 and $41 \%$ of the membrane mass of Geobacter and ND132, respectively, which is in agreement with a previous study. ${ }^{42}$ Sulfur K-edge XANES spectra (Figure S1 and Table S2) of whole cell and membrane samples demonstrated a high dominance of Org- $S_{\text {RED }}$, representing the sum of reduced organic $S$ functionalities organic disulfide (RSSR), monosulfide (RSR), and thiol (RSH) that cannot be separated by this methodology. Notably, our membrane samples are expected to include both outer and inner membrane structures. A similarly shaped XANES spectrum, highly dominated by Org- $S_{\text {RED }}$, was previously reported for the outer membrane of the bacterium Shewanella oneidensis. ${ }^{19}$ In contrast, oxidized sulfur such as sulfonate and sulfate were the dominant species in the extracellular solution (Figure S1). Given the reported excretion of LMM thiols from Geobacter ${ }^{35}$ and $\mathrm{ND}^{3} 32^{43}$ grown under similar conditions as in this study, it is suggested that some Org- $S_{\text {RED }}$ in the extracellular solution was represented by LMM thiols. It should be noted that a small amount of inorganic sulfide was detected by S XANES in the whole cell samples. Not surprisingly, the sulfide contribution to total $S$ in the sulfate-reducing bacterium ND132 sample was almost twice as high as in that the iron-reducing bacterium Geobacter. Notably, sulfide was not detected in the membrane samples, in the extracellular solution, or in the bacteria assay media of any of the two bacteria, using the methylene blue method. This result is in agreement with previous research showing that sulfide was undetectable under incubation in low sulfate concentration media. ${ }^{31,32,35}$

Chemical Structures of $\mathrm{Hg}(\mathrm{II})$ and Quantitation of Mem-RSH Functionalities on Bacteria Membranes Using Mercury $L_{\| 1}$-Edge EXAFS. As expected from previous studies of $\mathrm{NOM}^{28,44}$ and of bacteria membranes, ${ }^{8,45,46}$ we observed a significant loss of $\mathrm{Hg}_{\text {tot }}(\sim 10-64 \%)$ added to the bacterial membrane samples for EXAFS experiments (Table $1)$. These losses are explained mainly by $\mathrm{Hg}$ (II) reduction to $\mathrm{Hg}(0)$ caused by reductive functional groups in the membrane structures. Details about losses and processes causing them in different types of experiments are discussed further in connection to Figures S2 and S3 in the Supporting Information. The final determined $\mathrm{Hg}$ (II) concentration, remaining in the samples after the losses, was used when interpreting EXAFS data. Because the $\mathrm{Hg} \mathrm{L}_{\mathrm{III}}$-edge EXAFS results (Table 1 and Figure S4) for membranes of Geobacter did not reveal any clear differences between freeze-dried and frozen samples, data for freeze-dried and frozen samples were combined in the analyses of our results.

The average $\mathrm{Hg}-\mathrm{S}$ bond distance formed at the outer and inner membranes, represented by the peak at $\sim 1.9 \AA$ in the Fourier transformed (FT) spectra (Table 1 and Figure S4), varied from 2.34 to $2.39 \AA$ in the five characterized samples. This distance range is in line with previous EXAFS studies of $\mathrm{Hg}$ (II) added to the cell envelope (supposedly the outer cell membrane) of Geobacter with a reported $\mathrm{Hg}-\mathrm{S}$ bond distance of 2.32-2.38 $\AA^{19}$ At the lowest addition of $\mathrm{Hg}(\mathrm{II})$, corresponding to $4 \mu \mathrm{mol} \mathrm{g}{ }^{-1} \mathrm{C}$, the reported distance of $2.34 \AA$ is well in agreement with the previously determined 2coordinated $\mathrm{Hg}(\mathrm{NOM}-\mathrm{RS})_{2}$ structure in organic soils and in streamwater DOC. ${ }^{27,28}$ This distance is also in agreement with the $\mathrm{Hg}-\mathrm{S}$ distance in the range $2.32-2.35 \AA$ reported for the $\mathrm{Hg}(\mathrm{LMM}-\mathrm{RS})_{2}$ structure formed between $\mathrm{Hg}$ (II) and the LMM thiols Cys, Pen, and GSH. ${ }^{47-49}$ Combined with the information illustrated by the FT peak at $\sim 4 \AA$, representing the sum of three- and four-legged multiple scattering paths at the double $\mathrm{Hg}-\mathrm{S}$ distance (Figure S4), EXAFS data provide evidence for a 2 -coordinated, linear structure (close to $180^{\circ}$ angle) with the formula $\mathrm{Hg}(\mathrm{Mem}-\mathrm{RS})_{2}$ at this relatively low $\mathrm{Hg}$ (II) concentration. At higher additions of $\mathrm{Hg}$ (II), a firstcoordination shell $\mathrm{RO} / \mathrm{N}$ contribution ( $\mathrm{O}$ and $\mathrm{N}$ ligands cannot with certainty be separated by EXAFS data) was prevalent with the $\mathrm{Hg}-\mathrm{O} / \mathrm{N}$ bond distance varying between 2.03 and $2.08 \AA$, in agreement with previous $\mathrm{Hg} \mathrm{L} \mathrm{L}_{\mathrm{II}}$-edge EXAFS studies of Geobacter $(2.08 \AA)^{19}$ as well as with studies of NOM samples (2.04-2.09 $\AA){ }^{27}$ Due to increasing $\mathrm{Hg}-\mathrm{O} /$ $\mathrm{N}$ contribution with increasing $\mathrm{Hg}(\mathrm{II})$ addition, the first-shell peak was getting broader and shifted to shorter distances until a well-resolved peak dominated by the $\mathrm{Hg}-\mathrm{O} / \mathrm{N}$ distance appeared at $\sim 1.6 \AA$ (corresponding to a bond length of $2.03 \AA$ after correction for phase shift) for samples with $\mathrm{Hg}$ (II) concentrations of 215 and $406 \mu \mathrm{mol} \mathrm{g}^{-1} \mathrm{C}$ (Table 1 and Figure S4). The $\mathrm{Hg}-\mathrm{S}$ bond length was slightly longer (2.36-2.39 A) at the higher additions of $\mathrm{Hg}$ (II). One possible explanation for the longer $\mathrm{Hg}-\mathrm{S}$ distance may be some contribution from 3coordinated structures, $\mathrm{Hg}(\mathrm{Mem}-\mathrm{RS})_{3}$, known to have an average bond length varying in the range $2.40-2.51 \AA$ for $\mathrm{Hg}$ (II) complexes with LMM-RS, ${ }^{48,49}$ but it could likewise be due to the involvement of other types of thiols having slightly 
longer $\mathrm{Hg}-\mathrm{S}$ distances for 2-coordinated structures. Distortion of the structure due to steric hindrance effects could also affect bond lengths.

If 3-coordinated structures indeed would be of importance, they are expected to increase with decreasing $\mathrm{Hg}$ (II)/RSH ratios, which was not the case. The bond length $(2.34 \AA)$ and the multiple scattering peak clearly point at a high dominance of the linear $\mathrm{Hg}(\mathrm{Mem}-\mathrm{RS})_{2}$ structure at the lowest $\mathrm{Hg}$ (II) addition. Further, although less informative than bond lengths (due to a larger error of $\pm 15 \%$ and a covariation with the Debye-Waller factor), $\mathrm{CN}$ would be expected to increase with $\mathrm{Hg}$ (II) addition if the $\mathrm{Hg}(\mathrm{Mem}-\mathrm{RS})_{3}$ made up a significant contribution, which was not the case (Table 1). In addition, the occurrence of first shell $\mathrm{Hg}-\mathrm{O} / \mathrm{N}$ bond lengths of 2.03$2.08 \AA$ (Table 1 ) is suggesting 2 -coordinated structures. Some of these bonds may involve mixed structures of $\mathrm{Hg}-\mathrm{S}$ and $\mathrm{Hg}-\mathrm{O} / \mathrm{N}$ bonds in the first coordination shell. In summary, our EXAFS data points at a high dominance of 2-coordinated $\mathrm{Hg}(\mathrm{II})$ at the membranes of Geobacter with a shift from two Mem-RS to a mixture of Mem-RS and Mem-RO/N functionalities with increasing $\mathrm{Hg}$ (II) addition. Our results agree with the $\mathrm{Hg}$ EXAFS study of Geobacter cell envelopes conducted by Mishra et al. ${ }^{19}$ In their study the $\mathrm{Hg}-\mathrm{S}$ distance decreased from $2.38 \AA$ at $<5 \% \mathrm{Hg}$ (II) saturation of Mem-RSH groups (our calculation based on data reported in the study) to a minimum of $2.32 \AA$ when all thiol groups were more than saturated by $\mathrm{Hg}(\mathrm{II})$ and $\mathrm{RO} / \mathrm{N}$ groups were dominant (at 2.06 A). Similar to our interpretation, the authors argued that 3coordinated $\mathrm{Hg}(\mathrm{Mem}-\mathrm{RS})_{3}$ structures would only make a minor contribution (if any) in the cell envelope of Geobacter. ${ }^{19}$ In a recent study, ${ }^{46} \mathrm{Hg} \mathrm{L} \alpha_{1}$ fluorescence HR XANES data were collected on the outer membrane of Geobacter added $\mathrm{Hg}$ (II) corresponding to less than $0.1 \% \mathrm{Mem}-\mathrm{RSH}$ (our calculation based on data in the report). A model developed from 2-, 3-, and 4-coordinated $\mathrm{Hg}(\mathrm{II})$ model compound structures was used to interpret their data. The authors suggested that added $\mathrm{Hg}$ (II) was combining with membrane associated thiols in a mixture of 2- and 3-coordinated structures at $\mathrm{pH} 6.8$, but the average coordination could not be specified more in detail than to an "average coordination number of $2-3$ ". Because the method used is only semiquantitative, it is difficult to compare this result with the well-constrained $\mathrm{Hg}-\mathrm{S}$ bond lengths of $2.34 \pm 0.01 \AA$ as determined by EXAFS in our study (at $5 \%$ $\mathrm{Hg}$ (II) saturation of Mem-RS) and $2.38 \pm 0.01 \AA$ (at $<5 \%$ saturation of Mem-RSH) in the study of Mishra et al. at $\mathrm{pH}$ 7.0.

For ND132, our Hg EXAFS data were only collected at relatively high $\mathrm{Hg}$ (II) concentrations at which the Mem-RSH functional groups were fully saturated and bonding to $\mathrm{RO} / \mathrm{N}$ groups made significant contributions (Table 1 and Figure S4). The $\mathrm{Hg}-\mathrm{S}$ bond distance determined in the ND132 membrane samples (2.39 and $2.40 \AA$, respectively, for the two samples) was in fair agreement with the distance of 2.35$2.43 \AA$ reported for $\mathrm{Hg}(\mathrm{II})$ bonded to $\mathrm{ND} 132$ cell spheroplasts, ${ }^{9}$ which notably are devoid of the outer membrane and cannot be directly compared with our findings. Because we did not study the $\mathrm{Hg}$ speciation at this bacterium at sufficiently low $\mathrm{Hg}$ (II) additions, we have no information about possible 3-coordinated structures at low $\mathrm{Hg}$ (II) saturation of MemRSH groups.

EXAFS determined $\mathrm{CN}$ values of $\mathrm{Hg}-\mathrm{S}$ and $\mathrm{Hg}-\mathrm{O} / \mathrm{N}$ have previously been used to calculate the concentration of NOMassociated thiol groups based on an approach where all thiols groups are assumed to be involved in a 2-coordinated $\mathrm{Hg}(\mathrm{NOM}-\mathrm{RS})_{2}$ structure before $\mathrm{Hg}$ (II) is involved in the bonding with $\mathrm{RO} / \mathrm{N}$ groups, $\mathrm{Hg}(\mathrm{NOM}-\mathrm{RO})_{2} \cdot{ }^{26-28}$ Using this model, we were not able to simulate the Mem-RSH data on Geobacter as determined by $\mathrm{Hg}$ EXAFS (Figure S5a). It is expected that the bacteria membranes are more rigid than NOM structures and that the washing procedure is removing dissolved biomolecules and smaller fragments. Therefore, we propose a refined model to fit the $\mathrm{Hg}$ EXAFS data for the membranes (see the details in the Supporting Information). As a theoretical basis for our model, we suggest that because of steric effects only a limited number of Mem-RSH groups (designated Mem- $\mathrm{R}^{\mathrm{II}} \mathrm{SH}$ ) are located sufficiently close to each other to form a linear $\mathrm{Hg}\left(\mathrm{Mem}-\mathrm{R}^{\mathrm{II}} \mathrm{S}\right)_{2}$ structure. The large majority of the membranethiols (designated Mem- ${ }^{\mathrm{I}} \mathrm{SH}$ ) are instead expected to be involved in a 2-coordinated complex, $\mathrm{Hg}$ (Mem-R $\left.{ }^{\mathrm{I}} \mathrm{SRO}\right)$, composed of a mixture of Mem- $\mathrm{R}^{\mathrm{I}} \mathrm{SH}$ and neighboring $\mathrm{O} / \mathrm{N}$ functional groups.

With this model, the concentration of Mem- $\mathrm{R}^{\mathrm{II}} \mathrm{S}_{\text {tot }}([\mathrm{Mem}-$ $\left.\left.\mathrm{R}^{\mathrm{II}} \mathrm{SH}\right]+\left[\mathrm{Mem}-\mathrm{R}^{\mathrm{II}} \mathrm{S}^{-}\right]\right)$was calculated to be $20 \pm 5 \mu \mathrm{mol} \mathrm{g}^{-1}$ $\mathrm{C}( \pm \mathrm{SD})$ (corresponding to $2.1 \times 10^{-12} \mu \mathrm{mol}$ cell $^{-1}$ ) and the concentration of Mem- $\mathrm{R}^{\mathrm{I}} \mathrm{S}_{\text {tot }}\left(\left[\mathrm{Mem}-\mathrm{R}^{\mathrm{I}} \mathrm{SH}\right]+\left[\mathrm{Mem}-\mathrm{R}^{\mathrm{I}} \mathrm{S}^{-}\right]\right)$ was calculated to be $360 \pm 50 \mu \mathrm{mol} \mathrm{g}^{-1} \mathrm{C}$ (corresponding to $3.6 \times 10^{-11} \mu \mathrm{mol} \mathrm{cell}^{-1}$ ) for Geobacter membranes. Thus, the total concentration of thiol groups at the membranes, Mem$\mathrm{RS}_{\text {tot }}\left(\left[\mathrm{Mem}-\mathrm{R}^{\mathrm{II}} \mathrm{S}_{\text {tot }}\right]+\left[\mathrm{Mem}-\mathrm{R}^{\mathrm{I}} \mathrm{S}_{\text {tot }}\right]\right)$, was estimated to be 380 $\pm 50 \mu \mathrm{mol} \mathrm{g}{ }^{-1} \mathrm{C}$ (corresponding to $3.8 \times 10^{-11} \mu \mathrm{mol} \mathrm{cell}{ }^{-1}$ ). As shown in Figure S5b, the model showed a reasonable fit to the experimental $\mathrm{Hg}$ EXAFS data.

Using the same model, the thiol concentration of membranes of ND132 was estimated to be $19 \pm 5,330 \pm$ 40 , and $350 \pm 40 \mu \mathrm{mol} \mathrm{g}^{-1} \mathrm{C}$ (corresponding to $1.5 \times 10^{-10}$, $2.7 \times 10^{-9}$ and $2.8 \times 10^{-9} \mu \mathrm{mol}$ cell $\left.^{-1}\right)$ for Mem- ${ }^{\mathrm{II}} \mathrm{S}_{\text {tot }}$, Mem$\mathrm{R}^{\mathrm{I}} \mathrm{S}_{\text {tot }}$ and $\mathrm{Mem}-\mathrm{RS}_{\text {tot }}$ respectively. Given the limited $\mathrm{Hg}$ EXAFS data for this bacterium, our estimate rests on the assumption that the concentration of Mem- $\mathrm{R}^{\mathrm{II}} \mathrm{S}_{\text {tot }}$ made up 5\% of Mem-RS tot also for ND132 (as determined for Geobacter membranes). If the total $S$ accounts for $\sim 1 \%$ of bacterial cell mass (dry weight), ${ }^{42}$ Mem- $\mathrm{RS}_{\text {tot }}$ will account for $55 \%$ of total S and for $62 \%$ of Org-S $S_{\text {RED }}$ (as determined by S K-edge XANES) in membranes of Geobacter; whereas for ND132 Mem-RS accounts for $48 \%$ of total $S$ and $72 \%$ of Org-S $S_{\text {RED }}$.

Thiol functional group concentrations in membranes of Geobacter and ND132 determined here and in previous studies are listed in Table S3. Mishra et al. ${ }^{19}$ used two different methods to determine the Geobacter cell envelope concentration of thiols, assumed to represent the outer membrane concentration. They reported a concentration of $1000 \pm 300$ $\mu \mathrm{mol} \mathrm{g}{ }^{-1}$ dry cells, detected as fluorescence from $\mathrm{qBBr}$ used as the thiol probe, which would correspond to $2000 \mu \mathrm{mol} \mathrm{g}^{-1} \mathrm{C}$ if we assume a TOC mass concentration of $50 \%$. They also reported a thiol concentration of $67.8 \pm 22.8 \mu \mathrm{mol} \mathrm{g}^{-1}$ wet weight using a potentiometric titration method, with and without blocking of thiol groups with $\mathrm{qBBr}^{19}$ This thiol concentration would correspond to $550 \mu \mathrm{mol} \mathrm{g}^{-1} \mathrm{C}$ assuming $50 \%$ TOC content and a 4.2:1 wet/dry mass ratio (adopted from their study). Our estimate of the Mem-RSH concentration of $380 \pm 50 \mu \mathrm{mol} \mathrm{g}^{-1} \mathrm{C}$ thus corresponds fairly well with the potentiometric titration data $\left(550 \mu \mathrm{mol} \mathrm{g}^{-1} \mathrm{C}\right)$, while our estimate is lower than the estimate using $\mathrm{qBBr}$ as fluorescence probe. In another study using the $\mathrm{qBBr}$ fluorescence method, Thomas et al. ${ }^{46}$ obtained a Geobacter cell envelope concentration of $55.5 \pm 1.3 \mu \mathrm{mol} \mathrm{g}^{-1}$ wet cells, 
corresponding to $466 \mu \mathrm{mol} \mathrm{g}{ }^{-1} \mathrm{C}$ (assuming 50\% TOC content and 4.2:1 wet/dry mass ratio ${ }^{19}$ ). It should be pointed out that while our Mem-RSH estimate is expected to include both inner and outer membranes, Mishra et al. and Thomas et al. determined the cell surface thiols, which likely involves mostly the outer membranethiols. ${ }^{19,46}$

Notably, our results, as well as the results of Mishra et al. and Thomas et al. deviate largely from the report by Rao et al. ${ }^{50}$ on the membranethiols of Geobacter. Reported per cell, our determined concentration of Mem-RSH of $3.8 \times 10^{-11} \mu \mathrm{mol}$ cell $^{-1}$ is 3 orders of magnitude higher than the thiol concentration of $3.4 \times 10^{-14} \mu \mathrm{mol} \mathrm{cell}{ }^{-1}$ reported by Rao et al. We think the difference is due to methodology, where the fluorescence-labeling method using ThioGlo-1 as the probe for thiols seems to underestimate the thiol functionalities as compared to using EXAFS determinations and $\mathrm{qBBr}$ as a probe.

For ND132, our estimated Mem-RS ${ }_{\text {tot }}$ concentration of 2.8 $\times 10^{-9} \mu \mathrm{mol} \mathrm{cell}{ }^{-1}$ can only be compared with one other study in which TFP-4 was used as thiolate fluorescence probe. Wang et al. ${ }^{9}$ reported a thiol concentration in the isolated cell membranes of $2.8 \times 10^{-12} \mu \mathrm{mol} \mathrm{cell}^{-1}$ and in the spheroplast of $1.6 \times 10^{-11} \mu \mathrm{mol} \mathrm{cell}{ }^{-1}$ (recalculated based on Avogadro's constant). Thus, their reported membranethiol concentrations are $2-3$ orders lower than ours. In addition to differences in methodology, it should also be noted that differences in culture media, growth phase and growth conditions may also lead to differences in membranethiol concentrations. ${ }^{51,52}$

Competitive Ligand Exchange Experiments and Thermodynamic Calculations. Thermodynamic constants $(\log K)$ for the formation of $\mathrm{Hg}(\mathrm{II})$ complexes with Mem-RSH were calculated from equilibrium concentrations of $\mathrm{Hg}_{\text {tot }}$ and $\mathrm{Hg}(\mathrm{Cys})_{2}$ in the CLE experiments and by the chemical reactions in Table $\mathrm{S} 1$. The concentration of $\mathrm{Hg}_{\text {tot }}$ and $\mathrm{Hg}(\mathrm{Cys})_{2}$ was determined by CAAS and LC-ICPMS, respectively, and the sum of the concentrations of $\mathrm{Hg}(\mathrm{Mem}$ $\left.\mathrm{R}^{\mathrm{II}} \mathrm{S}\right)_{2}, \mathrm{Hg}(\mathrm{Cys})\left(\mathrm{Mem}-\mathrm{R}^{\mathrm{I}} \mathrm{S}\right)$ and $\mathrm{Hg}\left(\mathrm{Mem}-\mathrm{R}^{\mathrm{I}} \mathrm{SRO}\right)$ was calculated as the difference between $\mathrm{Hg}_{\text {tot }}$ and $\mathrm{Hg}(\mathrm{Cys})_{2}$. The concentration of $\mathrm{Hg}(\mathrm{Cys})_{2}$ did not change significantly with the selected reaction times of $1,24,48$ and $72 \mathrm{~h}(p>0.05$, ANOVA, Tukey-HSD) in our CLE-experiments (Figure S6). Thus, we conclude that chemical equilibrium between $\mathrm{Hg}$ (Cys) $)_{2}$ and $\mathrm{Hg}$ (II) complexed by membrane functional groups was attained already after $1 \mathrm{~h}$. This result can be compared with a previous study, in which Cys was added to a solution with $\mathrm{Hg}(\mathrm{NOM}-\mathrm{RS})_{2}$ complexes. Full equilibrium was demonstrated to be achieved already within minutes. ${ }^{28}$ Thus, we could safely use all our data determined at the reaction times of 1 to $72 \mathrm{~h}$ in thermodynamic calculations.

The major chemical reactions considered in our model, and their thermodynamic constants ( $\log K$ 's), are listed in Table $\mathrm{S} 1$. The $\mathrm{p} K_{\mathrm{a}}$ value of Mem-RSH of Geobacter was set to $9.5 \pm$ 0.2. ${ }^{19}$ The proposed dominant membrane associated species were $\mathrm{Hg}\left(\mathrm{Mem}-\mathrm{R}^{\mathrm{II}} \mathrm{S}\right)_{2}$ (reaction 9, Table S1), $\mathrm{Hg}(\mathrm{Cys})(\mathrm{Mem}-$ $\mathrm{R}^{\mathrm{I}} \mathrm{S}$ ) (reaction 10, Table S1), and $\mathrm{Hg}\left(\mathrm{Mem}-\mathrm{R}^{\mathrm{I}} \mathrm{SRO}\right.$ ) (reaction 11, Table S1), based on $\mathrm{Hg} \mathrm{L}_{\mathrm{III}}$-edge EXAFS experiments (Table 1 and Figure S4). Because of difficulties to separate chemical structures in the second coordination shell (e.g., $\mathrm{Hg}-$ $\mathrm{C}$ bond distances), there is no EXAFS data on the formation of a mixed complex, $\mathrm{Hg}(\mathrm{Cys})\left(\mathrm{Mem}-\mathrm{R}^{\mathrm{I}} \mathrm{S}\right)$ in the CLE experiments. However, based on previously reported experimental support for the mixed $\mathrm{Hg}(\mathrm{Cys})$ (NOM-RS) complex (reaction 8 , Table S1), ${ }^{28}$ and mixed $\mathrm{Hg}(\mathrm{II})$-LMM thiol com- plexes, ${ }^{29,53-55}$ as well as on calculated linear free-energy relationships (LFER) for mixed ligand complex formation, ${ }^{56}$ the $\mathrm{Hg}(\mathrm{Cys})\left(\mathrm{Mem}-\mathrm{R}^{\mathrm{I}} \mathrm{S}\right)$ complex is likely to form in the $\mathrm{Hg}$ (II)-Cys-bacterium membrane system. In studies of the $\mathrm{Hg}$ (II)-Cys-NOM system using CLE experiments, Song et al. ${ }^{28}$ showed that the $\log K$ values for the formation of $\mathrm{Hg}(\mathrm{NOM}-\mathrm{RS})_{2}$ and $\mathrm{Hg}(\mathrm{Cys})(\mathrm{NOM}-\mathrm{RS})$ were positively correlated, which is expected according to linear free energy relationships (LFER). ${ }^{5 t}$ In fact, the two $\log K$ values were very similar when the differences in the $\mathrm{p} K_{\mathrm{a}}$ values of Cys and NOM-RSH were taken into account. ${ }^{28}$ Therefore, in order to include the $\mathrm{Hg}(\mathrm{Cys})\left(\mathrm{Mem}-\mathrm{R}^{\mathrm{I}} \mathrm{S}\right)$ species in our model, the $\log K$ difference between $\mathrm{Hg}\left(\mathrm{Mem}-\mathrm{R}^{\mathrm{II}} \mathrm{S}\right)_{2}$ and $\mathrm{Hg}(\mathrm{Cys})$ (Mem$\left.\mathrm{R}^{\mathrm{I}} \mathrm{S}\right)$ was set to the same value as the difference determined between $\mathrm{Hg}(\mathrm{NOM}-\mathrm{RS})_{2}$ and $\mathrm{Hg}(\mathrm{Cys})(\mathrm{NOM}-\mathrm{RS}),{ }^{28}$ as calculated by eq 1 :

$$
\begin{aligned}
& \log K_{\mathrm{Hg}\left(\mathrm{Mem}-\mathrm{R}^{\mathrm{II}}\right)_{2}}-\log K_{\mathrm{Hg}(\mathrm{Cys})\left(\mathrm{Mem}-\mathrm{R}^{\mathrm{I} S}\right)} \\
& \quad=\log K_{\mathrm{Hg}(\mathrm{NOM}-\mathrm{RS})_{2}}-\log K_{\mathrm{Hg}(\mathrm{Cys})(\mathrm{NOM}-\mathrm{RS})}-0.5
\end{aligned}
$$

where -0.5 is the difference in $\mathrm{pK}_{\mathrm{a}}$ between Mem-RSH and NOM-RSH (Table S1). Similarly, the difference in $\log K$ between $\mathrm{Hg}\left(\mathrm{Mem}-\mathrm{R}^{\mathrm{II}} \mathrm{S}\right)_{2}$ and $\mathrm{Hg}\left(\mathrm{Mem}-\mathrm{R}^{\mathrm{I} S R O}\right)$ was calculated by eq 2 :

$$
\begin{aligned}
& \log K_{\mathrm{Hg}\left(\mathrm{Mem}-R^{\mathrm{II}} \mathrm{S}\right)_{2}}-\log K_{\mathrm{Hg}\left(\mathrm{Mem}-\mathrm{R}^{\mathrm{I}} \mathrm{SRO}\right)} \\
& \quad=\log K_{\mathrm{Hg}(\mathrm{NOM}-\mathrm{RS})_{2}}-\log K_{\mathrm{Hg}(\text { NOM-RSRO })}-0.5
\end{aligned}
$$

The $\log K$ values of $\mathrm{Hg}\left(\mathrm{Mem}-\mathrm{R}^{\mathrm{II}} \mathrm{S}\right)_{2}$ (reaction 9, Table S1), $\mathrm{Hg}$ (Cys) (Mem-R ${ }^{\mathrm{I}} S$ ) (reaction 10, Table S1), and $\mathrm{Hg}(\mathrm{Mem}-$ $\mathrm{R}^{\mathrm{I}} \mathrm{SRO}$ ) (reaction 11, Table S1) were then calculated to be $39.1 \pm 0.2,38.1 \pm 0.1$, and $25.6 \pm 0.1( \pm S D)$, respectively. The model was optimized by the software $\mathrm{R}$ package PHREEQC and a minimum merit-of-fit, $\Sigma$ (model - experiment $)^{2} /$ Eexperiment ${ }^{2}$, was obtained at $2.5 \%$, with experiment denoting the measured concentration of $\mathrm{Hg}(\mathrm{Cys})_{2}$ and model denoting the modeled $\mathrm{Hg}(\mathrm{Cys})_{2}$ concentration (Figure 1). Note that the $\log K$ values represent an average of possibly several different types of thiol groups associated with the bacterium inner and outer membrane.

Our determined $\log K$ value of the mixed $\mathrm{Hg}(\mathrm{Cys})(\mathrm{Mem}-$ $\mathrm{R}^{\mathrm{I}} \mathrm{S}$ ) complex can be compared with the LFER calculated by Dyrssen and Wedborg. ${ }^{56}$ They proposed a statistical relationship between the $\log K$ values of mixed ligation complex $\mathrm{HgAB}$ $\left(\mathrm{Hg}^{2+}+\mathrm{A}^{-}+\mathrm{B}^{-} \rightleftharpoons \mathrm{HgAB}\right)$ and complexes $\mathrm{HgA}_{2}$ and $\mathrm{HgB}_{2}$ : $\log K_{\mathrm{HgAB}}=\log 2+0.5\left(\log K_{\mathrm{HgA}_{2}}+\log K_{\mathrm{HgB}_{2}}\right)$. Using this relationship, the $\log \mathrm{K}$ of $\mathrm{Hg}(\mathrm{Cys})\left(\mathrm{Mem}-\mathrm{R}^{\mathrm{I}} \mathrm{S}\right)$ is calculated to be 38.6 (based on the $\log \mathrm{K}$ of 37.5 for $\mathrm{Hg}(\mathrm{Cys})_{2}$ and 39.1 for $\left.\mathrm{Hg}\left(\mathrm{Mem}-\mathrm{R}^{\mathrm{II}} \mathrm{S}\right)_{2}\right)$, which is reasonably close to our result of 38.1 .

For the membranes of ND132, the log K's for $\mathrm{Hg}(\mathrm{Mem}$ $\left.\mathrm{R}^{\mathrm{II}} \mathrm{S}\right)_{2}, \mathrm{Hg}(\mathrm{Cys})\left(\mathrm{Mem}-\mathrm{R}^{\mathrm{I}} \mathrm{S}\right)$, and $\mathrm{Hg}\left(\mathrm{Mem}-\mathrm{R}^{\mathrm{I}} \mathrm{SRO}\right)$ were calculated to be $39.2 \pm 0.2,38.2 \pm 0.1$, and $25.7 \pm 0.1$, respectively, at a merit-of-fit of $5 \%$ (Figure S7). Similar to the case of Geobacter, the $\mathrm{p} K_{\mathrm{a}}$ value for ND132 Mem-RSH was set to $9.5 \pm 0.2 .^{9,19,25}$ It should be pointed out that the $\mathrm{Hg}_{\text {tot }}$ concentration in the ND132 membrane CLE experiment was unavailable and it was therefore set to the average concentration obtained in the Geobacter membrane CLE experiment $(0.4 \mu \mathrm{M})$, after accounting for $\mathrm{Hg}(\mathrm{II})$ losses. Therefore, the uncertainly (SD) of the $\log K$ values may be larger than 0.2 for ND132. Yet, our results indicate that the log 


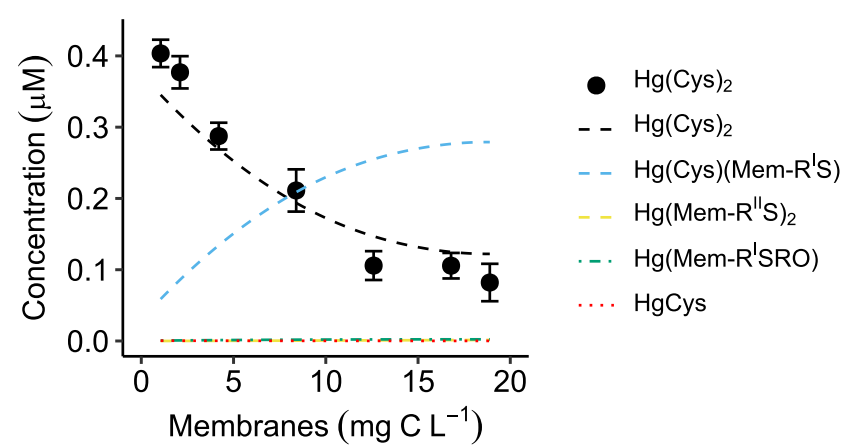

Figure 1. Experimentally determined $\mathrm{Hg}(\mathrm{Cys})_{2}$ concentration $( \pm \mathrm{SD}$, $n=4)$ as a function of Geobacter membrane concentration in the competitive ligand exchange experiment. $\mathrm{pH} \sim 4.0$ and $I=10 \mathrm{mM}$ $\mathrm{NaClO}_{4}$. Different concentrations of membranes $\left(1-19 \mathrm{mg} \mathrm{C} \mathrm{L}{ }^{-1}\right.$ corresponding to $0.4-7.1 \mu \mathrm{M}$ Mem- $\mathrm{RS}_{\text {tot }}$ ) were pre-equilibrated in $0.5 \mu \mathrm{M} \mathrm{Hg}\left(\mathrm{NO}_{3}\right)_{2}$ for $24 \mathrm{~h}$ followed by the addition of Cys to reach a final concentration of $2 \mu \mathrm{M}$. The concentration of $\mathrm{Hg}(\mathrm{Cys})_{2}$ was measured at equilibrium. Dashed lines demonstrate the modeled concentrations, optimized by $\mathrm{R}$ software using $\mathrm{R}$ package PHREEQC to minimize the merit-of-fit, $\Sigma(\text { model }- \text { experiment })^{2} / \Sigma$ experiment ${ }^{2}$, at $2.5 \%$.

$K$ values for the formation of $\mathrm{Hg}$ (II) complexes with membrane thiol functional groups are quite similar for the two different bacteria. As shown by calculations in the Supporting Information, the $\log \mathrm{K}$ of $\mathrm{Hg}$-thiol complexes formed with Cys, NOM, and membranes only differ by a maximum $0.5 \log$ units at $\mathrm{pH}$ values when thiols are protonated.
An Internally Consistent Chemical Speciation Model for Bacterium-LMM Thiol-NOM Systems and its Environmental Implications. Cellular uptake is a membrane passing process and a critical step for bacterial $\mathrm{Hg}(\mathrm{II})$ methylation. Although the mechanism of the molecular processes of $\mathrm{Hg}$ (II) bacterial uptake and methylation remain unclear, it has been demonstrated in laboratory ${ }^{31,32,35}$ and mesocosm studies ${ }^{58-60}$ that the chemical speciation of $\mathrm{Hg}$ (II) in soils, sediments, and waters plays an important role in $\mathrm{MeHg}$ formation and subsequent uptake in organisms. Several field studies have reported significant, positive relationships between porewater concentrations of $\mathrm{Hg}$ (II) and rates of $\mathrm{MeHg}$ formation in marine systems, ${ }^{61-63}$ and tundra lakes. ${ }^{64}$ Identification of the $\mathrm{Hg}(\mathrm{II})$ species responsible for these relationships has proven to be more difficult. ${ }^{65,66} \mathrm{~A}$ major difficulty is that several $\mathrm{Hg}$ (II) species are expected to be bioavailable at different rates of uptake, which needs to be known, or at least estimated from experimental systems, if field data are to be simulated. Thermodynamic models have further been biased by including uncertain stability constants and nonconfirmed chemical species. ${ }^{5}$ Finally, because most models have been constructed from a range of thermodynamic experiments conducted with variable methodology, very few thermodynamic models are internally consistent.

In this study, we provide membrane thiol concentrations of Geobacter and ND132, and we have identified their surface complexes formed with $\mathrm{Hg}(\mathrm{II})$, i.e., $\mathrm{Hg}\left(\mathrm{Mem}-\mathrm{R}^{\mathrm{II}} \mathrm{S}\right)_{2}$, $\mathrm{Hg}$ (Cys)(Mem-R $\left.{ }^{\mathrm{I}} \mathrm{S}\right)$, and $\mathrm{Hg}\left(\mathrm{Mem}-\mathrm{R}^{\mathrm{I}} \mathrm{SRO}\right)$, and their corresponding thermodynamic constants. By combining these parameters with constants previously reported for complexes
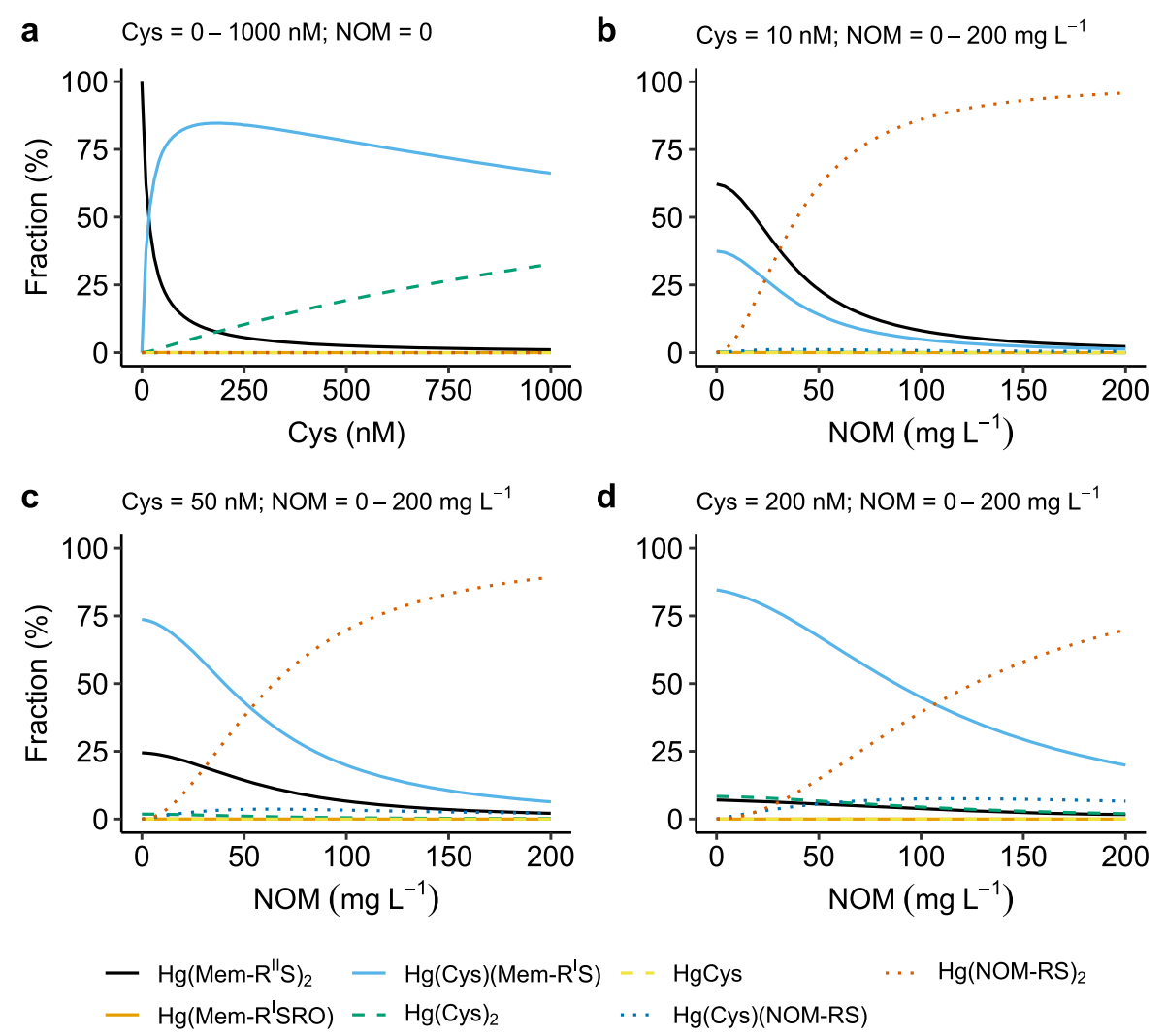

Figure 2. $\mathrm{Hg}$ (II) speciation as a function of Cys and Suwannee River natural organic matter (NOM) concentration under environmentally relevant condition: $\mathrm{Hg}(\mathrm{II})=1 \mathrm{ng} \mathrm{L}^{-1}$, Cys $=0-1000 \mathrm{nM}$, cell abundance $=2 \times 10^{8}$ cells mL $^{-1}$, NOM $=0-200 \mathrm{mg} \mathrm{L}^{-1}$ (corresponding to $0-1.5 \mu \mathrm{M}$ NOM-RSH based on the NOM-RSH concentration of $\left.7.5 \mu \mathrm{mol} \mathrm{g}^{-1} \mathrm{NOM}^{28}\right), \mathrm{pH}=7$, and ionic strength $=10 \mathrm{mM}$. 
formed between $\mathrm{Hg}(\mathrm{II})$ and 15 naturally occurring LMM thiols, ${ }^{29}$ as well as with thiol groups associated with Suwannee River $\mathrm{NOM}^{28}$ we can calculate the chemical speciation of $\mathrm{Hg}$ (II) in contact with bacteria under nonsulfidic environmental conditions. Because the experimentally determined parameters combined in such a model are all derived by the same CLE methodology, the data set represents an internally consistent thermodynamic model that can be used to simulate the chemical speciation of $\mathrm{Hg}(\mathrm{II})$ in reasonably complex systems relevant for nonsulfidic conditions in the environment (Table S1). Because Cys is used as a competitive ligand in all the CLE experiments, constants determined for the reaction between $\mathrm{Hg}$ (II) and functional groups associated with bacterial membranes, LMM thiols, and NOM all rely on a $\log K$ of 37.5 set for reaction 4 (Table S1). ${ }^{29}$ The strength of this approach is that, although it can be argued that there are other reported values on the constant for reaction 4 in the literature, the model is internally consistent and will thus accurately describe the distribution of $\mathrm{Hg}(\mathrm{II})$ among membranes, LMM thiols, and NOM.

In Figure 2, the chemical speciation of $\mathrm{Hg}$ (II) in a system with the bacterium Geobacter is illustrated as a function of varying concentrations of $\operatorname{NOM}(\mathrm{aq})$ and the LMM thiol Cys. The amino acid Cys is known to be produced by Geobacter, reaching concentrations on the order of $100 \mathrm{nM}$ in incubation experiments. ${ }^{35}$ The $\mathrm{Hg}$ (II) concentration was fixed at $1 \mathrm{ng} \mathrm{L}^{-1}$, which is a common level in freshwaters, and $\mathrm{pH}$ and the ionic strength were fixed at 7.0 and $10 \mathrm{mM}$, respectively. The cell abundance of Geobacter was set to $2 \times 10^{8}$ cells $\mathrm{mL}^{-1}$, a number typically selected for conventional bacterial incubation experiments. Because the outer and inner membranes were not separated in our experiments, the outer membrane thiols were for simplicity assumed to represent $50 \%$ of Mem- $\mathrm{RS}_{\text {tot }}(1.9 \times$ $10^{-11} \mu \mathrm{mol}$ cell $\left.^{-1}\right)$. This means we assume the densities of thiols are equal $\left(\mu \mathrm{mol} \mathrm{g}{ }^{-1}\right)$ at both the inner and outer membranes and that they contribute equally to our reported density per cell.

Figure $2 \mathrm{a}$ illustrates that in absence of $\mathrm{NOM}, \mathrm{Hg}(\mathrm{II})$ is complexed by the cell membrane mainly in the structure $\mathrm{Hg}\left(\mathrm{Mem}-\mathrm{R}^{\mathrm{II}} \mathrm{S}\right)_{2}$ when the Cys concentration is less than $\sim 20$ $\mathrm{nM}$. When the Cys concentration exceeds $\sim 20 \mathrm{nM}$, the $\mathrm{Hg}(\mathrm{Cys})\left(\mathrm{Mem}-\mathrm{R}^{\mathrm{I}} \mathrm{S}\right)$ structure will gradually take over and dominate even up to $1 \mu \mathrm{M}$ Cys. Figure $2 \mathrm{~b}-\mathrm{d}$ further demonstrates the effect of NOM on the speciation of $\mathrm{Hg}$ (II) in this system. When the concentration of both Cys and NOM are relatively low (e.g., $10 \mathrm{nM}$ Cys and $20 \mathrm{mg} \mathrm{L}^{-1} \mathrm{NOM}$ corresponding to $150 \mathrm{nM}$ NOM-RSH according to Song et $\mathrm{al}^{28}{ }^{2}$ ), all three complexes, $\mathrm{Hg}\left(\mathrm{Mem}-\mathrm{R}^{\mathrm{II}} \mathrm{S}\right)_{2}, \mathrm{Hg}(\mathrm{Cys})(\mathrm{Mem}-$ $\left.\mathrm{R}^{\mathrm{I}} \mathrm{S}\right)$, and $\mathrm{Hg}(\mathrm{NOM}-\mathrm{RS})_{2}$, make significant contributions. With increased NOM concentration, the $\mathrm{Hg}(\mathrm{NOM}-\mathrm{RS})_{2}$ complex will gradually take over as the dominant species. The NOM concentrations at which $\mathrm{Hg}(\mathrm{Cys})\left(\mathrm{Mem}-\mathrm{R}^{\mathrm{I}} \mathrm{S}\right)$ and $\mathrm{Hg}$ (NOM-RS $)_{2}$ concentrations are approximately equal are 25 , 50 , and $100 \mathrm{mg} \mathrm{L}^{-1}$ at 10,50 , and $200 \mathrm{nM}$ Cys, respectively. All these combinations are expected to cover relevant conditions in soils and sediments, depending on microbial activity and redox potential.

The model demonstrates a very significant association of $\mathrm{Hg}$ (II) with cell membranes, even at high concentrations of NOM and LMM thiols in aqueous phase covering the $10 \mathrm{nM}$ to $1 \mu \mathrm{M}$ range, conditions expected to be encountered in soils and sediments. Notably, under the circumstances in soils and waters when LMM concentrations exceed $10 \mathrm{nM},{ }^{67} \mathrm{Hg}$ (II) is expected to be dominated by complexes formed as a mixture of Mem- $\mathrm{RS}^{\mathrm{I}} \mathrm{H}$ and various types of LMM thiols at bacterium membrane surfaces. Although Cys, NOM-RSH, and Mem$\mathrm{RSH}$ have similar affinities for $\mathrm{Hg}$ (II) at neutral $\mathrm{pH}$ (when thiols are kept protonated), the 2-coordinated $\mathrm{Hg}\left(\mathrm{Mem}-\mathrm{R}^{\mathrm{II}} \mathrm{S}\right)_{2}$ structure only dominates at very low LMM thiol concentrations. This is because Mem- $\mathrm{R}^{\mathrm{II}} \mathrm{S}_{\text {tot }}$ only contributes to $5 \%$ of Mem-RS tot. It should be noted that a potential complex composed of a mixture of $\mathrm{Hg}$ (II) with NOM-RSH and Mem$\mathrm{RSH}$ ligation is not included in this model. The rationale for excluding this species is that such a complex may be constrained by steric hindrance effects.

Overall, our results point at the quantitative importance of a mixed ligation between LMM thiols and Mem-RSH functionalities under environmentally relevant conditions. The question that remains to be answered is what role such a complex may have for the internalization of $\mathrm{Hg}(\mathrm{II})$ and its methylation in Geobacter. The bonding of $\mathrm{Hg}$ (II) to membrane functional groups was not included in the study of Adediran et al. ${ }^{35}$ on the same bacteria. They demonstrated that the thermodynamically weaker complexes involving $\mathrm{O}$ and $\mathrm{Cl}$ ligands showed larger methylation rate constants than 2coordinate complexes involving only LMM thiols but noted that the weaker complexes are less likely to be quantitatively important in natural environments under thermodynamic equilibrium conditions. Also our modeling shows that complexes involving $\mathrm{O}$ and $\mathrm{Cl}$ bonds in the first coordination shell are too weak to be quantitatively important at a $\mathrm{Hg}$ (II)

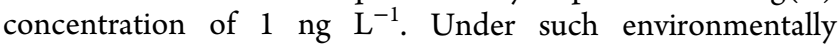
relevant conditions, the uptake and methylation rate of complexes formed with thiols associated with LMM molecules, $\mathrm{NOM}$, and bacterial membranes will regulate $\mathrm{MeHg}$ formation.

We recommend the use of this internally consistent thermodynamic model in future experimental studies aiming at resolving the mechanisms of $\mathrm{Hg}$ (II) uptake and transformation in bacterium-NOM-LMM thiol systems, in the presence of Geobacter and ND132. In order to be able to specifically address the question whether cell membrane associated thiol functionalities inhibit, stimulate, or are indifferent to $\mathrm{Hg}$-species cellular uptake, a further differentiation of thiol groups associated with specific locations at membranes is required. Notably, our chemical modeling (Figure 2) does not apply to sulfidic conditions, where aqueous $\mathrm{Hg}-\mathrm{S}$ complexes and solid $\mathrm{HgS}$ (s) phases need to be included. To get an internally consistent data set covering also sulfidic conditions, the thermodynamics of, e.g., $\mathrm{Hg}(\mathrm{Cys})_{2}$ and aqueous $\mathrm{Hg}-\mathrm{S}$ complex formation need to be related in the same experiment.

\section{ASSOCIATED CONTENT}

\section{Supporting Information}

The Supporting Information is available free of charge at https://pubs.acs.org/doi/10.1021/acs.est.0c01751.

Description of bacterial growth media, membrane

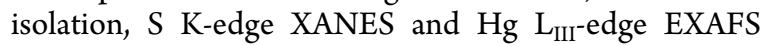
experiments, Mem-RSH concentration calculations, experimental losses of $\mathrm{Hg}(\mathrm{II})$, and thermodynamic calculations of reactions with thiols in protonated form; list of selected chemical reactions and thermodynamic constants, $\mathrm{S}$ K-edge XANES result, and reported Mem-RSH concentrations in previous studies; S K-edge XANES and $\mathrm{Hg} \mathrm{L}_{\mathrm{III}}{ }^{-}$edge EXAFS spectra and model fits, 
Mem-RSH calculation model, loss of $\mathrm{Hg}$ (II), CLE experimental results, and $\mathrm{Hg}(\mathrm{II})-\mathrm{Mem}-\mathrm{RSH}$ thermodynamic stabilities of ND132 (PDF)

\section{AUTHOR INFORMATION}

\section{Corresponding Authors}

Yu Song - Department of Forest Ecology and Management, Swedish University of Agricultural Science, SE-901 83 Umea, Sweden; (1) orcid.org/0000-0002-8610-0525;

Email: yu.song@slu.se

Ulf Skyllberg - Department of Forest Ecology and Management, Swedish University of Agricultural Science, SE-901 83 Umeå, Sweden; 10 orcid.org/0000-0001-6939-8799; Phone: +46 (0)90-786 84 60; Email: ulf.skyllberg@slu.se

\section{Authors}

Gbotemi A. Adediran - Department of Chemistry, Umea University, SE-901 87 Umea, Sweden

Tao Jiang - Department of Forest Ecology and Management, Swedish University of Agricultural Science, SE-901 83 Umea, Sweden

Shusaku Hayama - Diamond Light Source, Didcot, Oxfordshire OX11 ODE, United Kingdom

Erik Björn - Department of Chemistry, Umeå University, SE90187 Umeå, Sweden; 이이. orcid.org/0000-0001-9570-8738

Complete contact information is available at: https://pubs.acs.org/10.1021/acs.est.0c01751

\section{Notes}

The authors declare no competing financial interest.

\section{ACKNOWLEDGMENTS}

The authors acknowledge Dr. Yuwei Wang at Department of Environmental Sciences, Rutgers University, for assistance on the cell abundance estimation; Dr. Chenyan $\mathrm{Ma}$ at Beijing Synchrotron Radiation Facility (Beamline 4B7A) for assistance with the sulfur K-edge XANES spectroscopy measurements; and Sofia Diaz-Moreno and Ann-Kathrin Geiger at Diamond Light Source (Beamline I20-scanning, project SP9157) for assistance at the DLS beamline and sample handling. This work was funded by the Swedish Research Council (VR) project Sino-Swedish Mercury Management FrameworkSMaReF (2013-6978), the VR project (621-2014-5370), and Carl Trygger Foundation CTS 17:423 to U.S. and by the Kempe Foundations (JCK-1501, SMK-2745, SMK-1243).

\section{REFERENCES}

(1) Hsu-Kim, H.; Kucharzyk, K. H.; Zhang, T.; Deshusses, M. A. Mechanisms Regulating Mercury Bioavailability for Methylating Microorganisms in the Aquatic Environment: A Critical Review. Environ. Sci. Technol. 2013, 47, 2441-2456.

(2) Parks, J. M.; Johs, A.; Podar, M.; Bridou, R.; Hurt, R. A.; Smith, S. D.; Tomanicek, S. J.; Qian, Y.; Brown, S. D.; Brandt, C. C.; et al. The Genetic Basis for Bacterial Mercury Methylation. Science 2013, 339, 1332-1335.

(3) Podar, M.; Gilmour, C. C.; Brandt, C. C.; Soren, A.; Brown, S. D.; Crable, B. R.; Palumbo, A. V.; Somenahally, A. C.; Elias, D. A. Global Prevalence and Distribution of Genes and Microorganisms Involved in Mercury Methylation. Sci. Adv. 2015, 1, No. e1500675.

(4) Regnell, O.; Watras, C. J. Microbial Mercury Methylation in Aquatic Environments: A Critical Review of Published Field and Laboratory Studies. Environ. Sci. Technol. 2019, 53, 4-19.

(5) Skyllberg, U. Competition among Thiols and Inorganic Sulfides and Polysulfides for $\mathrm{Hg}$ and $\mathrm{MeHg}$ in Wetland Soils and Sediments under Suboxic Conditions: Illumination of Controversies and Implications for $\mathrm{MeHg}$ Net Production. J. Geophys. Res. 2008, 113, $1-14$.

(6) Graham, A. M.; Bullock, A. L.; Maizel, A. C.; Elias, D. A.; Gilmour, C. C. Detailed Assessment of the Kinetics of Hg-Cell Association, $\mathrm{Hg}$ Methylation, and Methylmercury Degradation in Several Desulfovibrio Species. Appl. Environ. Microbiol. 2012, 78, 7337-7346.

(7) Liu, Y. R.; Lu, X.; Zhao, L.; An, J.; He, J. Z.; Pierce, E. M.; Johs, A.; Gu, B. Effects of Cellular Sorption on Mercury Bioavailability and Methylmercury Production by Desulfovibrio Desulfuricans ND132. Environ. Sci. Technol. 2016, 50, 13335-13341.

(8) Hu, H.; Lin, H.; Zheng, W.; Rao, B.; Feng, X.; Liang, L.; Elias, D. A.; Gu, B. Mercury Reduction and Cell-Surface Adsorption by Geobacter Sulfurreducens PCA. Environ. Sci. Technol. 2013, 47, 10922-10930.

(9) Wang, Y.; Schaefer, J. K.; Mishra, B.; Yee, N. Intracellular Hg(0) Oxidation in Desulfovibrio Desulfuricans ND132. Environ. Sci. Technol. 2016, 50, 11049-11056.

(10) Lin, H.; Hurt, R. A.; Johs, A.; Parks, J. M.; Morrell-Falvey, J. L.; Liang, L.; Elias, D. A.; Gu, B. Unexpected Effects of Gene Deletion on Interactions of Mercury with the Methylation-Deficient Mutant $\Delta$ hgcAB. Environ. Sci. Technol. Lett. 2014, 1, 271-276.

(11) Thomas, S. A.; Tong, T.; Gaillard, J.-F. Hg(II) Bacterial Biouptake: The Role of Anthropogenic and Biogenic Ligands Present in Solution and Spectroscopic Evidence of Ligand Exchange Reactions at the Cell Surface. Metallomics 2014, 6, 2213-2222.

(12) Barkay, T.; Miller, S. M.; Summers, A. O. Bacterial Mercury Resistance from Atoms to Ecosystems. FEMS Microbiol. Rev. 2003, 27, 355-384.

(13) Slaveykova, V. I.; Wilkinson, K. J. Predicting the Bioavailability of Metals and Metal Complexes: Critical Review of the Biotic Ligand Model. Environ. Chem. 2005, 2, 9-24.

(14) Aristilde, L.; Xu, Y.; Morel, F. M. M. Weak Organic Ligands Enhance Zinc Uptake in Marine Phytoplankton. Environ. Sci. Technol. 2012, 46, 5438-5445.

(15) Flynn, S. L.; Szymanowski, J. E.; Fein, J. B. Modeling Bacterial Metal Toxicity Using a Surface Complexation Approach. Chem. Geol. 2014, 374, 110-116.

(16) Zhao, C.-M.; Wilkinson, K. J. Biotic Ligand Model Does Not Predict the Bioavailability of Rare Earth Elements in the Presence of Organic Ligands. Environ. Sci. Technol. 2015, 49, 2207-2214.

(17) Zhao, C.-M.; Campbell, P. G. C.; Wilkinson, K. J. When Are Metal Complexes Bioavailable? Environ. Chem. 2016, 13, 425-433.

(18) Fein, J. B. Advanced Biotic Ligand Models: Using Surface Complexation Modeling to Quantify Metal Bioavailability to Bacteria in Geologic Systems. Chem. Geol. 2017, 464, 127-136.

(19) Mishra, B.; Shoenfelt, E.; Yu, Q.; Yee, N.; Fein, J. B.; Myneni, S. C. B. Stoichiometry of Mercury-Thiol Complexes on Bacterial Cell Envelopes. Chem. Geol. 2017, 464, 137-146.

(20) Daughney, C. J.; Siciliano, S. D.; Rencz, A. N.; Lean, D.; Fortin, D. $\mathrm{Hg}(\mathrm{II})$ Adsorption by Bacteria: A Surface Complexation Model and Its Application to Shallow Acidic Lakes and Wetlands in Kejimkujik National Park, Nova Scotia, Canada. Environ. Sci. Technol. 2002, 36, 1546-1553.

(21) Dunham-Cheatham, S.; Farrell, B.; Mishra, B.; Myneni, S.; Fein, J. B. The Effect of Chloride on the Adsorption of Hg onto Three Bacterial Species. Chem. Geol. 2014, 373, 106-114.

(22) Johnson, C. R.; Fein, J. B. The Effect of Metal Loading on Bacterial Hg Adsorption. Chem. Geol. 2018, 498, 106-114.

(23) Yi, L.; Li, H.; Sun, L.; Liu, L.; Zhang, C.; Xi, Z. A Highly Sensitive Fluorescence Probe for Fast Thiol-Quantification Assay of Glutathione Reductase. Angew. Chem., Int. Ed. 2009, 48, 4034-4037.

(24) Joe-Wong, C.; Shoenfelt, E.; Hauser, E. J.; Crompton, N.; Myneni, S. C. B. Estimation of Reactive Thiol Concentrations in Dissolved Organic Matter and Bacterial Cell Membranes in Aquatic Systems. Environ. Sci. Technol. 2012, 46, 9854-9861.

(25) Yu, Q.; Szymanowski, J.; Myneni, S. C. B.; Fein, J. B. Characterization of Sulfhydryl Sites within Bacterial Cell Envelopes 
Using Selective Site-Blocking and Potentiometric Titrations. Chem. Geol. 2014, 373, 50-58.

(26) Qian, J.; Skyllberg, U.; Frech, W.; Bleam, W. F.; Bloom, P. R.; Petit, P. E. Bonding of Methyl Mercury to Reduced Sulfur Groups in Soil and Stream Organic Matter as Determined by X-Ray Absorption Spectroscopy and Binding Affinity Studies. Geochim. Cosmochim. Acta 2002, 66, 3873-3885.

(27) Skyllberg, U.; Bloom, P. R.; Qian, J.; Lin, C.-M.; Bleam, W. F. Complexation of Mercury(II) in Soil Organic Matter: EXAFS Evidence for Linear Two-Coordination with Reduced Sulfur Groups. Environ. Sci. Technol. 2006, 40, 4174-4180.

(28) Song, Y.; Jiang, T.; Liem-Nguyen, V.; Sparrman, T.; Björn, E.; Skyllberg, U. Thermodynamics of $\mathrm{Hg}$ (II) Bonding to Thiol Groups in Suwannee River Natural Organic Matter Resolved by Competitive Ligand Exchange, $\mathrm{Hg} \mathrm{L}_{\mathrm{III}}$-Edge EXAFS and ${ }^{1} \mathrm{H}$ NMR Spectroscopy. Environ. Sci. Technol. 2018, 52, 8292-8301.

(29) Liem-Nguyen, V.; Skyllberg, U.; Nam, K.; Björn, E. Thermodynamic Stability of Mercury(II) Complexes Formed with Environmentally Relevant Low-Molecular-Mass Thiols Studied by Competing Ligand Exchange and Density Functional Theory. Environ. Chem. 2017, 14, 243-253.

(30) Caccavo, F.; Lonergan, D. J.; Lovley, D. R.; Davis, M.; Stolz, J. F.; McInerney, M. J. Geobacter Sulfurreducens Sp. Nov., a Hydrogenand Acetate-Oxidizing Dissimilatory Metal-Reducing Microorganism. Appl. Environ. Microbiol. 1994, 60, 3752-3759.

(31) Schaefer, J. K.; Morel, F. M. High Methylation Rates of Mercury Bound to Cysteine by Geobacter Sulfurreducens. Nat. Geosci. 2009, 2, 123-126.

(32) Schaefer, J. K.; Rocks, S. S.; Zheng, W.; Liang, L.; Gu, B.; Morel, F. M. M. Active Transport, Substrate Specificity, and Methylation of $\mathrm{Hg}$ (II) in Anaerobic Bacteria. Proc. Natl. Acad. Sci. U. S. A. 2011, 108, 8714-8719.

(33) Sandrini, S. M.; Haigh, R.; Freestone, P. P. Fractionation by Ultracentrifugation of Gram Negative Cytoplasmic and Membrane Proteins. Bio-Protocol 2014, 4, No. e1287.

(34) Gorby, Y. A.; Beveridge, T. J.; Blakemore, R. P. Characterization of the Bacterial Magnetosome Membrane. J. Bacteriol. 1988, 170, 834-841.

(35) Adediran, G. A.; Liem-Nguyen, V.; Song, Y.; Schaefer, J. K.; Skyllberg, U.; Björn, E. Microbial Biosynthesis of Thiol Compounds: Implications for Speciation, Cellular Uptake, and Methylation of $\mathrm{Hg}(\mathrm{II})$. Environ. Sci. Technol. 2019, 53, 8187-8196.

(36) Cline, J. D. SPECTROPHOTOMETRIC DETERMINATION OF HYDROGEN SULFIDE IN NATURAL WATERS1. Limnol. Oceanogr. 1969, 14, 454-458.

(37) Dunham-Cheatham, S.; Mishra, B.; Myneni, S.; Fein, J. B. The Effect of Natural Organic Matter on the Adsorption of Mercury to Bacterial Cells. Geochim. Cosmochim. Acta 2015, 150, 1-10.

(38) R Core Team. R: A Language and Environment for Statistical Computing; 2020.

(39) Parkhurst, D. L.; Appelo, C. A. J. Description of Input and Examples for PHREEQC Version 3-A Computer Program for Speciation, Batch-Reaction, One-Dimensional Transport, and Inverse Geochemical Calculations; Techniques and Methods; U.S. Geological Survey, 2013; Book 6.

(40) Charlton, S. R.; Parkhurst, D. L. Modules Based on the Geochemical Model PHREEQC for Use in Scripting and Programming Languages. Comput. Geosci. 2011, 37, 1653-1663.

(41) Ucar, I.; Pebesma, E.; Azcorra, A. Measurement Errors in R. R J. 2019, 10, 549-557.

(42) Barton, L. L.; Goulhen, F.; Bruschi, M.; Woodards, N. A.; Plunkett, R. M.; Rietmeijer, F. J. M. The Bacterial Metallome: Composition and Stability with Specific Reference to the Anaerobic Bacterium Desulfovibrio Desulfuricans. BioMetals 2007, 20, 291-302.

(43) Liem-Nguyen, V.; Huynh, K.; Gallampois, C.; Björn, E. Determination of Picomolar Concentrations of Thiol Compounds in Natural Waters and Biological Samples by Tandem Mass Spectrometry with Online Preconcentration and Isotope-Labeling Derivatization. Anal. Chim. Acta 2019, 1067, 71-78.
(44) Jiang, T.; Skyllberg, U.; Wei, S.; Wang, D.; Lu, S.; Jiang, Z.; Flanagan, D. C. Modeling of the Structure-Specific Kinetics of Abiotic, Dark Reduction of $\mathrm{Hg}(\mathrm{II})$ Complexed by $\mathrm{O} / \mathrm{N}$ and $\mathrm{S}$ Functional Groups in Humic Acids While Accounting for TimeDependent Structural Rearrangement. Geochim. Cosmochim. Acta 2015, 154, 151-167.

(45) Lin, H.; Morrell-Falvey, J. L.; Rao, B.; Liang, L.; Gu, B. Coupled Mercury-Cell Sorption, Reduction, and Oxidation on Methylmercury Production by Geobacter Sulfurreducens PCA. Environ. Sci. Technol. 2014, 48, 11969-11976.

(46) Thomas, S. A.; Mishra, B.; Myneni, S. C. Cellular Mercury Coordination Environment, and Not Cell Surface Ligands, Influence Bacterial Methylmercury Production. Environ. Sci. Technol. 2020, 54, 3960-3968.

(47) Jalilehvand, F.; Leung, B. O.; Izadifard, M.; Damian, E. Mercury(II) Cysteine Complexes in Alkaline Aqueous Solution. Inorg. Chem. 2006, 45, 66-73.

(48) Leung, B. O.; Jalilehvand, F.; Mah, V. Mercury(II) Penicillamine Complex Formation in Alkaline Aqueous Solution. Dalton Trans 2007, 4666-74.

(49) Mah, V.; Jalilehvand, F. Glutathione Complex Formation with Mercury(II) in Aqueous Solution at Physiological pH. Chem. Res. Toxicol. 2010, 23, 1815-23.

(50) Rao, B.; Simpson, C.; Lin, H.; Liang, L.; Gu, B. Determination of Thiol Functional Groups on Bacteria and Natural Organic Matter in Environmental Systems. Talanta 2014, 119, 240-247.

(51) Yu, Q.; Fein, J. B. Controls on Bacterial Cell Envelope Sulfhydryl Site Concentrations: The Effect of Glucose Concentration during Growth. Environ. Sci. Technol. 2017, 51, 7395-7402.

(52) Fein, J. B.; Yu, Q.; Nam, J.; Yee, N. Bacterial Cell Envelope and Extracellular Sulfhydryl Binding Sites: Their Roles in Metal Binding and Bioavailability. Chem. Geol. 2019, 521, 28-38.

(53) Hilton, B.; Man, M.; Hsi, E.; Bryant, R. NMR Studies of Mercurial-Halogen Equilibria. J. Inorg. Nucl. Chem. 1975, 37, 10731077.

(54) Pei, K. L.; Sooriyaarachchi, M.; Sherrell, D. A.; George, G. N.; Gailer, J. Probing the Coordination Behavior of $\mathrm{Hg} \mathrm{2+}, \mathrm{CH} 3 \mathrm{Hg}+$, and Cd $2+$ towards Mixtures of Two Biological Thiols by HPLC-ICPAES. J. Inorg. Biochem. 2011, 105, 375-381.

(55) Pyreu, D. F.; Ryzhakov, A. M.; Kozlovskii, E. V.; Gruzdev, M. S.; Kumeev, R. S. Mixed-Ligand Complex Formation of Mercury (II) Ethylenediaminetetraacetate with Cysteine and Methionine in Aqueous Solution. Inorg. Chim. Acta 2011, 371, 53-58.

(56) Dyrssen, D.; Wedborg, M. The Sulphur-Mercury(II) System in Natural Waters. Water, Air, Soil Pollut. 1991, 56, 507-519.

(57) Wells, P. R. Linear Free Energy Relationships. Chem. Rev. 1963, 63, 171-219.

(58) Jonsson, S.; Skyllberg, U.; Nilsson, M. B.; Westlund, P.-O.; Shchukarev, A.; Lundberg, E.; Björn, E. Mercury Methylation Rates for Geochemically Relevant $\mathrm{Hg}$ (II) Species in Sediments. Environ. Sci. Technol. 2012, 46, 11653-11659.

(59) Jonsson, S.; Skyllberg, U.; Nilsson, M. B.; Lundberg, E.; Andersson, A.; Björn, E. Differentiated Availability of Geochemical Mercury Pools Controls Methylmercury Levels in Estuarine Sediment and Biota. Nat. Commun. 2014, 5, 4624.

(60) Zhu, W.; Song, Y.; Adediran, G. A.; Jiang, T.; Reis, A. T.; Pereira, E.; Skyllberg, U.; Björn, E. Mercury Transformations in Resuspended Contaminated Sediment Controlled by Redox Conditions, Chemical Speciation and Sources of Organic Matter. Geochim. Cosmochim. Acta 2018, 220, 158-179.

(61) Hammerschmidt, C. R.; Fitzgerald, W. F. Geochemical Controls on the Production and Distribution of Methylmercury in Near-Shore Marine Sediments. Environ. Sci. Technol. 2004, 38, 14871495.

(62) Hammerschmidt, C. R.; Fitzgerald, W. F. Methylmercury Cycling in Sediments on the Continental Shelf of Southern New England. Geochim. Cosmochim. Acta 2006, 70, 918-930. 
(63) Hollweg, T. A.; Gilmour, C. C.; Mason, R. P. Mercury and Methylmercury Cycling in Sediments of the Mid-Atlantic Continental Shelf and Slope. Limnol. Oceanogr. 2010, 55, 2703-2722.

(64) Hammerschmidt, C. R.; Fitzgerald, W. F.; Lamborg, C. H.; Balcom, P. H.; Tseng, C.-M. Biogeochemical Cycling of Methylmercury in Lakes and Tundra Watersheds of Arctic Alaska. Environ. Sci. Technol. 2006, 40, 1204-1211.

(65) Benoit, J. M.; Gilmour, C. C.; Mason, R. P.; Heyes, A. Sulfide Controls on Mercury Speciation and Bioavailability to Methylating Bacteria in Sediment Pore Waters. Environ. Sci. Technol. 1999, 33, 951-957.

(66) Drott, A.; Lambertsson, L.; Björn, E.; Skyllberg, U. Importance of Dissolved Neutral Mercury Sulfides for Methyl Mercury Production in Contaminated Sediments. Environ. Sci. Technol. 2007, $41,2270-2276$.

(67) Liem-Nguyen, V.; Skyllberg, U.; Björn, E. Thermodynamic Modeling of the Solubility and Chemical Speciation of Mercury and Methylmercury Driven by Organic Thiols and Micromolar Sulfide Concentrations in Boreal Wetland Soils. Environ. Sci. Technol. 2017, $51,3678-3686$. 